\title{
Long Run Leadership Production and Selection Model for Democracies in Africa
}

\author{
Adewole Musiliu Adeolu \\ Department of Economics, School of Management Technology, Federal University Of Technology, \\ Akure Ondo State Nigeria
}

\begin{abstract}
Within the broad agenda of economic development, we suggest a model of leadership production and selection which shows how the optimal number of people required to bridge the gap between actual and potential economic performance could be raised and selected into public office. The honesty and competence of those selected helps to overcome the considerable inertial against take-off of economic development by inculcating common values in peoples from across diverse groups. By imbibing common norms through the school system, we generate economics of scale which otherwise would not be available in scattered, self-governing and well-run communities. The selection process uses the school system to make social progress an important leadership concern and economic advancement an important part of individual utility function. In generating this special breed through the school system, the incompetent individuals are screened out from the competent individuals as well as the honest from the dishonest ones. The honest individuals are sorted into three ability categories for public governance for the three tiers of government in democratic societies. The ultimate aim is to motivate every family towards producing individuals whose characters and competences are compatible with the requirements of developmental states.
\end{abstract}

Keywords: Leadership failure, participation costs, pooling equilibrium, separating equilibrium, screening costs, social welfare, etc

DOI: $10.7176 / \mathrm{JESD} / 10-10-01$

Publication date:May $31^{\text {st }} 2019$

\subsection{Introduction}

Corruption often defined as the abuse of public office for private gain is a massive global industry. A careful estimate by World Bank team gives the average payments of bribes per year to public officials at about a $1 \$$ trillion, with lower and upper bounds of between $\$ 600$ million and $\$ 1.5$ trillion (Kaufman and Mastruzzi, 2005). This estimate excludes several means of plundering the commonwealth, including the direct withdrawal of state resources from the till. It excludes the widespread use of state resources in projects with negative social surplus (Robinson and Torvik, 2005). A previous study by IMF in 1998 (see Alonso-Terme, Davoodi, and Gupta, 1998) reports that aggregate magnitude of money laundering will be between 2 to $5 \%$ of the global GDP. A disproportionately large sum of this global aggregate is paid in developing countries, and more so in Africa. Acemoglu, Verdier and Robinson (2004) make explicit reference to several leaders in developing countries who stole massive amounts of money. Shleifer and Vishny, 1994) cite good examples of public officials receiving sidepayments and illegal loans from public enterprises or engaging in socially costly redistribution in favour of political supporters. Corruption that affects economic development is a serious threat to both central and sub-national governments (Khemani, 2004; Reinikka, and Svensson, 2004).

One immediate implication of abuse of public office is the sub-optimal provision of public goods. Aside this, government is generally unable to protect rights and enforce contracts. Thus, government contracts with citizens are frequently violated, with no third party able to help enforce the terms of the agreements. Routinely, the politically powerful use intimidation and corruption to subvert the operation of legal and regulatory institutions of state (Glaeser, Scheinkmanb, Shleifer, 2003). Beneficial and growth-promoting transactions are avoided because government will either violate contracts or citizens in contractual relations will not honour the explicit terms of their contracts. This is compounded by the incomplete nature of contracts where parties cannot ex ante draw up comprehensive contract to care of all contingencies ex post. The deep shadow of a weak and corrupt state can crowd out transactions that could enhance the growth process. Therefore, under-development becomes selfsustaining.

To resolve the problem of widespread corruption, a broad category of approaches has been advocated. One is the introduction of democracy and improvements in quality of state institutions (North and Weingast, 1989; Ake, 1996, Achebe, 1987). Another option will be to allow the spontaneous evolution of order on larger scale from selfgoverning and optimal communities identified in a number of studies by Ostrom $(1997,2001)$ and others (Sethi and Somanathan, 1996; Dixit, 2003). At least a number of studies have shown how group of individuals who are miles apart can trade honestly with each other (Greif, 2006). The least appreciated, but one for which this piece is written is to draw on the attributes of competence and honesty in men and women to foster economic development. The simple assignment in this instance is to design rules that excludes dishonest and incompetent individuals 
(Adewole, 2015). We can extend this approach to ensure continuous supply of those whose competence and honesty is required for economic development.

This extension is informed by the fact there is no elastic supply of this kind of individuals to provide leadership at all levels of governance, for the public sector as well as the private sector. There is therefore the need to create a set of distinct organizations (Collier, 1996) to supply trained individuals to provide appropriate leadership in the public and private sectors. A high corruption-equilibrium for any society leaves little incentives for people to want to be honest (Tirole, 1996). This is so because individual's past behaviour is observed with a noise. Others tend to judge her by the group characteristics to which she belongs. An honest individual who belongs to corrupt group is perceived as corrupt. To transform to a better state is very difficult, but our approach is a coordination device to encourage every member of the corrupt group to start acting right. This approach is also informed by the fact leadership plays fundamental role in catalysing economic development, for nations and organisations (Besley et al. 2011; Bai and Zhou 2014; Buckley et al 2014; Galasso and Nannicini 2011; Luo 2010).

The rest of this piece is organized as follows. In section two we discuss the institutional approach and discuss the limitations of this approach. We then discuss the self-governing approach and its limitations as well in section three. We sketch the approach of this piece in section four and provide a simple model in section five. Necessary conclusions are drawn in section six.

\subsection{The Institutional Approach}

While agency problems in the public sector are in some ways similar to that of the private sector, their implications for development are far more serious. The public sector and those who control it wields enormous resources and power. Their structure and efficiency therefore have far reaching consequences for the results produced by the private sector, and generally, economic development. The more difficult part is the fact that violations from political elites in the public sector cannot be corrected by any other third party. Thus, when political elites fail to protect private property rights, enforce contracts, provide public goods and give credible commitments, private governance activities, even when they are positive, do not achieve socially optimal results. In most instances, economic governance in the private sector, which could substitute for the failure of the public sector, is destroyed (Hoff and Karla, 2001). When they operate efficiently and optimally, the scale of operations do not provide scope for substantial economic benefits to be realized. Both pre-industrial experience of modern economies in the West, the persistent challenges of underdevelopment in many countries of the world, the stagnation of Latin American countries and the crushing poverty in Africa, amply indicate that automatic mechanism to trigger development do not exist.

In one special instance, Coase theorem fails woefully in the public sector because the mechanism for credible commitment does not exist (Acemoglu 2003; Acemoglu, Johnson and Robinson, 2005). The root of credible commitment problem is the inseparability of distribution and efficiency. The public sector also presents a special case where the gap between the principal and the agent is large, and the opportunity for regular interaction does not exist. Having layers of governance systems, with a local government closest to the people may have reduced the gap between the people and the governing elites. However, it has barely scratched the agency problem on its head ((Keefer and Khemani, 2005; Khemani, 2006). With numerous and deeply divided principals, and agents operating at different tiers of government, control is also compounded. Coordination costs tend to rise dramatically for the principals, with agents set on the loose. The mere fact that political elites can collude rather than compete with each other makes the matter worse for principals who are often not united to present a common platform for change. Political elites, who are the agents, know how to divide the principals, particularly through the use of costly redistributive strategies (Robinson and Ragnar, 2005; Khemani, 2004). Furthermore some information constraint poses important challenges for the control of political agents.

Fundamental institutional transformation is therefore seen as one sure way out of these agency problems. Appropriate institutions will check expropriation of public resources, make property rights more secure, compel the impartial enforcement of contracts by the state and offer sufficient incentives for political elites to provide optimal quantity of public goods. The change in political institutions that transfer de facto power from the political elites will make credible commitment more likely. This institutional transformation is important where trade is to expand beyond personal and repeated transactions to impersonal trade of non-repeated nature. In the latter type of trade, scale economies are sufficiently large enough to make initial development self-sustaining when an impartial arbiter exist to enforce contracts.

To put this discussion in proper context, it is important to refer to the situation in England before the glorious revolution of 1688. From the account of North and Weingast (1989), the unconstrained monarchy often resorted to the sale of land and monopolies, the confiscation of private wealth, debt repudiation and outright theft of public resources. This situation limited the opportunity for beneficial trade relations between private citizens on one hand and between citizens and government on the other hand. After the revolution, political power was redistributed to constrain the monarchy and improve the enforcement of property rights. This was done by establishing a parliament with powers to exercise fiscal authority. One immediate consequence of this is that risk premium on 
public loans fell dramatically, and interest rates dropped sharply for both public and private sectors borrowers. Thus, change in how political power is allocated led to far-reaching changes in economic institutions. To make their gains durable, the English gentry and merchants who defeated the monarchy in the Glorious revolution, altered political institutions that stripped the monarchy of fiscal authority. Further changes in political institutions came with the continuous extension of suffrage, not just in England but other parts of Europe (Prezworski et al, 2000). This led to a significant rise in the supply of public goods (Lizzeri and Persico, 2004). The gradual but sustained efforts to create an impartial and impersonal arbiter out of the state make contracting parties less likely to break their agreements. Cooperation was therefore self-enforcing because defection yielded zero benefits when no private individual is strong enough to subvert the regulatory and legal institutions of the state.

The emergence of parliament that determined fiscal policy of government effectively created the separation of powers, where each arm of government helps to check the other. The separation of power affects the incentive constraints facing non-benevolent dictators and the amount of rents that can be assessed (Laffont and Martimort, 1998). Thus, the emergence of the parliament, which at first exercised fiscal authority but later extended it influences beyond that, is one instance where internal revolution in the organization of public bureaucracy could limit the harmful effect of centralization of authority as was the case before the Glorious revolution in England and many other parts of Europe.

The other positive side of strong and effective institutions is that they limit the degree to which force or corruption influences outcome of dispute between parties. Otherwise, the legal system will offer security for people to acquire private property (Glaeser and Shleifer, 2002). The degree to which coercion is deployed is an important determinant of the legal system. The equilibrium outcome depends on the extent to which the local population is predisposed to the use of force in securing favourable court judgement. Where the local population favoured the use of extreme force, as was the case in France, it was better to accept the biased verdicts of state-protected judges than to allow independent local juries which are often coerced to deliver unfair judgements. When courts could not be subverted by local warlords as was the case in England, juries, independent of the monarchy evolved common laws (Glaeser and Shleifer, 2002). Thus, in France, civil law which has greater regulations, provided less secure property rights and less efficient government evolved. The case of the common law in England was different and a sharp contrast to the France's case.

Good governance is shaped by the institutional environment. This probably explains why the Group of Eight decision in July 2005 to double aid and debt relief regarded good governance as a matter of high priority. A report by Africa Commission was even more explicit; "Good governance is the key.... Unless there are improvements in capacity, accountability, and reducing corruption... other reforms will have limited impact." There is both the explicit confidence that institutional improvements will bring significant improvements in living conditions of people in developing countries, particularly the poverty stricken people of Sub-Saharan Africa. In fact, one optimistic calculation by Acemoglu et al (2001) says if Nigeria should attain the institutional quality of Chile, her capita income would be seven times what it is presently.

While we admit that institutions play a fundamental role in long run development, institutions are by no means a quick fix. Institutions take a long time to evolve and require several mediating channels to have positive effects. The literature has indeed raise doubts as to whether the immediate impact of change in political institution is a lower level of interest rates. Sussman and Yafeh (2005) argue that the institutional reforms of the post-Glorious revolution did not lead to sharp drop in interest rates. Their argument is that the interest rates remained high, and even rose after the Glorious revolution.

Stasavage (2002a, 2003) argues that institutional reforms which led to credible commitments in England and other parts of the Western Europe depended on the structure of partisan interests in the society, the existence of cross-issue and the degree to which government debt was delegated. The credible commitments are not independent of the state type, as city-states in Europe borrowed on easier terms and paid lower interests than larger countries (Stasavage, 2007a). Thus, the enforcement of public debt repayment was a decreasing function of the size of states. Though the empirical study by Stasavage (2002b) accepts that political institutions that put checks on political elites allow them to make credible commitments, checks and balances do not constitute necessary conditions for credible commitment. There are other avenues for securing credible commitment beyond the institutional reforms. It took more many decades after the Glorious revolution for the parliament to be controlled by those associated with public debt and for credible commitment to be secured (Stasavage, 2007b). Thus, credible commitment is dependent on partisan control. This probably explains why interest rates never fell in the immediate post-revolution years as noted by Sussman and Yafeh (2005).

There is also the great difficulty in developing the common front required to limit or punish sovereignty that infringe on the economic and political rights of the people. A considerable lag of time might be required to evolve a self-enforcing democratic stability because information asymmetries and other forms of pronounced divisions among citizens create enormous coordination problems (Weingast, 1997). The empirical study (Humphreys and Bates, 2005) of the relationship between competitive institutions and extractive policies yielded different results for a global sample and the African sample. In the global sample, competitive institutions were associated with 
less extractive policies. The Africa's subsample did not produce strong relationship between competitions and growth-friendly policies. The implication is Africa political institutions have not matured enough to produce the positive results. This perhaps amplifies the conclusion of Plateau (2000) that beyond rising economic opportunities, a society will need a critical mass of cultural energies to overcome the initial resistance to change. This points to the inability of informal institutions to respond rapidly to emerging economic opportunities in the immediate environment. Political elites invest in de facto political power so that the ex post effects of de jure constitutional change is not apparent (Acemoglu and Robinson, 2006 and 2008). In a constitutionally mature country such as the US, the logic that mobility of people could inhibite bad governance is turned on its head. This happens when politicians like Mr. Curley increased electoral support for himself by using bad policies to drive voters opposed to him away from his constituency (Glaeser and Shleifer, 2005). Generally, the incompleteness of institutions because of cognitive limitations of those drafting the rules implies other factors could play a key role in driving economic development (Wariboko, 1998). Beyond institutions that limit the exercise of arbitrary power, two other options present itself. First, community governance could offer some opportunities for advancing development, and the next section, we discuss the possibility of social advancement though community governance, equally drawing attention to its limitations.

Secondly, we discuss leadership the role of political leadership, which can be a useful complement to institutions and community. This is stressed because, disciplined political leaders might be internally constrained from formulating and implementing that divert public resources into private use, thus fast-tracking development and institutional development. Their actions or inactions could serve as an important coordination device, lowering transaction costs and encouraging beneficial intergroup economic relations. The perspective of Majumdar and Mukand (2008) is that leadership is vital to the transformation of political institutions, organisations and implementation of social and economic reforms. Gray and McPherson (2001) posit that the modest progress or absence of it recorded by Africa is due to leadership. A more specific argument along the same line of thought has been advanced by Iyoha (2008) for Nigeria. In a recent empirical study of the role of leadership on economic growth, Jones and Olken (2005) found that leadership matters, significantly more so for poor countries. Empirical support for this line of thinking has also come from Besley, et al (2011), arguing that leader's education has positive impact on economic growth. Since educated leaders are more likely to be selected into public office in democracies (Besley and Reynal-Querol, 2011), this study exploits the democratic system to outline the rules that will facilitate the selection into public offices of those that can accelerate the development of their country production and selection process.

\subsection{Community Governance}

An alternative approach to fast-tracking development has come under the growing literature of economic governance. Dixit (2009) defined economic governance as 'the structure and functioning of the legal and social institutions that support economic activity and economic transactions by protecting property rights, enforcing contracts, and taking collective action to provide physical and organizational infrastructure'. Properly functioning economic governance system, from the discussion of the previous section, will depend on the strength of formal institutions of state. The pertinent issue is to critically investigate the possibility of another organizational form that can deliver with as much efficiency as, if not better, the state. The follow up will to investigate whether this network of optimal communities can generate scale of activities that will initiate and sustain economic development across the whole state.

This section will attempt to sketch the landmark studies which attempt to uncover non-state organizational structures that provide economic governance, and examined the limits of this governance type within the context of society whose sole objective is to maximize the welfare of its citizens. These governance forms have operated at the levels of work teams, credit associations, partnerships, local commons and residential neighbourhood (Bowles and Herbert, 2002) and at times in long distance trade where monitoring could be costly. Examining alternative modes is particularly appealing in societies where state or governance failure has produced extreme poverty for vast majority of the people. Will private ordering fill the gap left by inept states? One interesting piece suggests that a unique equilibrium exists in that there is a fraction of people who are honest or dishonest, so that both activities generate the same level of returns (Frank, 1987). Grossman and Kim (2000) argue that some sort of moral revival breaks out when most people in a society are found on the wrong side of the moral spectrum.

The basic essence of economic governance, as is presented in this piece, is to show how alternative forms of non-state governance can protect property rights, enforce contracts and provide public goods. These are duties which rational individuals do not have incentives to provide singly or even as a member of a group except some form of coercion is applied (Olson, 1965). Often, the coercion will have to come from the state. This constitutes what the literature generally referred to as social dilemmas, sometimes presented in game theory perspective.

In a path breaking book, Ostrom (1990) shows that there is an alternative social arrangement that allow individuals in interdependent relationship to organise themselves into groups and prevent the excessive exploitation of common pool resources (CPR) at minimal administrative costs. She outlines basic rules or 
principles for the exploitation of these common resources and illustrates cases of great successes and failure. These include the demarcation of group boundary, crafted rules are matched to meet local needs and conditions, involvement of group members in changing rules if need be, external coercive force acknowledges the right of the group to device their own rules, the existence of a mechanism for monitoring member's conduct, the use of graduated sanctions from the mild to the most severe, the presence and access to low-cost dispute resolution mechanism and the hierarchical organizations with different layers of governance systems. The work itself cuts across both developed and developing countries. This work remains the signpost for follow up studies, challenging the conventional dictum that state-directed intervention might be required for optimal organization of commons in enforcing contracts or providing public goods. Her works uncover how a segment of society with persons willing to cooperate or communicate each other can set up their groups.

Other parallel experimental studies using game theory approach such as ultimatum game (UG), gift exchange game (GEG), trust game (TG), dictator game (DG), and public good game (PGG) ${ }^{1}$ to establish the fact that standard theory may not apply to a wide range of situations, including those that involve the provision of collective goods (check Guth, Schmittberger and Schwarse, 1982; Camerer and Thaler 1995). The responders' behaviour does not conform to the theory of self-interest. Because proposers anticipate responders would reject what they term an unfair wage offer, experimental results (see Foresyth etal 1994; Roth, Prannikar, Okun-Fujiwara and Zamar, 1991; Suleiman, 1999) showed that offers were higher under UG than DG. In fact, under UG, the frequently made offers were targeted at getting optimum anticipated income for the proposer. In several PGGs (see Davies and Thaler, 1988 , for a survey of the literature) repeated for close to ten periods, with randomly selected group members, contribution to public good is done by 25 percent of the group members in the final period, but improved to 75 percent when group members were allowed to punish defectors ${ }^{2}$ ( Fehr and Gachter, 2000). Group punishment is the weapon which drives conformity, some punishment involve pecuniary loss while others involve the loss of status and ostracism.

In summarizing the insights of numerous experimental studies, Ostrom (2000) notes the following well established facts: contributions of between 40 and 60 percent of their endowments in providing public goods in one-shot game as well the first round of finite-repeated games; contributions fall in repeated games with a lower bound of 30 percent contributing to public goods; individuals cooperate when she is aware others will cooperate; face-to-face communication enhances cooperation that sustains the game to the final one; learning the games better leads to more cooperation; willingness to punish non-cooperators or defectors; and degree of contribution to public goods is affected by different contexts in various communities.

Therefore, it is well-established now that groups of individuals can provide different kinds of public goods without the intervention of the state. This is what Ostrom, Walker and Gardner (1992) called governance without the sword, at least without the sword of the state. In fact, local communities can provide policing more efficiently than the state organized security services (Elinor Ostrom and Gordon Whitaker, 1973). The communities also tend to overcome, to a large extent, the opportunism that characterizes incomplete contracts, because of constant interaction among members of the community. The mutual flow of reciprocity within the community and between members discourages opportunism even when explicit rules of the community do not legislative against it. The watershed in self-government is the dramatic increase in the formation groups, about 478,000 groups having close to 14.3 million members, involved in watershed, irrigation, microfinance, forest conservation, pest management and farmers' research (Pretty and Ward, 2001)

Economic governance on a broader scale have featured in the works of Greif(1989, 1993 and 2006), Milgrom, North and Weingast (1990) and Greif, Milgrom and Weingast (1994). The works explained what kind of alternative institutions evolved privately in an environment where contract enforcement capacity of the state was limited. In some instances, private courts were set up to encourage honest conducts, punish contract violators, generate information about trading parties in distant locations, amass evidence against defectors and ensure payments levied through the court process. In another instance, reputation mechanism was deployed to tackle huge organizational problems associated with long distance trade between merchants and the agents abroad. Tradition of good reputation was used by rational agents in maintaining trade with distant merchants in the presence of asymmetric information. Merchant guilds were actively promoted by the rulers of trading centers to counter the threat of the state confiscating the wealth of the merchants.

${ }^{1}$ Ultimatum game (UG) is a game involving a pair of persons who have to share a fixed amount of money. One person, called the proposer, decides how the money is to be shared while the other party, called the responder, receives or rejects what the proposer has offered. In the case of rejection both parties receives nothing. Dictator game (DG) is like the ultimatum game except that the rejection by the responder does not affect the payoff of the proposer. In Gift Exchange game (GEG), the proposer makes a specified wage offer to the responder. In turn, the responder can accept or reject the offer. In case of acceptance, he must exert some level of effort. In Trust game (TG), the proposer is given some money by the experimenter. The proposer can give between zero and the total amount offered by the experimenter to the responder. The amount given the responder is tripled and the responder is allowed to send between zero and the tripled amount back to the proposer. Public good game (PGGs) involves a group of people who can determine how much of their endowments to give as contribution to a public good. The endowment of each participant in the experiment is given to them by the experimenter.

${ }^{2}$ Those who failed to contribute to the provision of public good. 
More than anything else, these works show the possibility of building private institutions over a long distance than suggested by the works of Ostrom (1990, 1992 and 2000). But for developing countries in general and Africa in particular, it is difficult to see how we can reproduce non-state institutions on a grander scale to fast-track development. A recent experimental study in Cameroun by Etang, Fielding and Knowles (2010) shows that trust declines with social distance, in fact between one village and the next. The absence of trust among Africans has deep roots in the history of slave trade, when many villages were frequently attacked in order to capture slaves (Nunn, 2008; Nunn and Wantchekon, 2011). Dixit (2003) says that self-enforcing honesty is possible between close neighbours but decreases as the distance goes beyond an optimal size. Even in Europe, economic exchange is to a large extent determined by religion, a history of conflicts and genetic similarities (Guiso, Sapienza and Zingales, 2008). While some form of private governance can take place at the village level in many African countries, it doubtful if the scale of the governance activities can extend as far as those illustrated in Greif (2006). Even in the seminal study of Greif (2006), these private arrangements described in Greif remains an inadequate explanation for the rise of the West (Clark, 2007) and Greif admitted the system collapsed over time. The scale of activities at the villages cannot generate increasing returns when the scope of impersonal and non-repeated trade is inhibited by factors such as lack of trust. More worrisome is the possibility that inefficient states can crowd out private governance (Bowles and Gintis, 2002).

Finally, the two approaches discussed so far should be seen as complementary. Between mega institutions which are incomplete for several reasons and community level governance hindered by scale of operations, we could build the bridge that connects the different levels of governance systems by generalized norms, partly internalized through the school system and through other means of socialization, to develop skills and competences required for building institutions with increasing returns at the central level of governance and institutions with constant returns at the community. It is possible to break down the barrier of distrust through the school system where people of diverse backgrounds learn common norms of governance ethics. It is not just public sector governance but equally about appropriate corporate governance in the private sector.

\subsection{Internalized Norms}

The main emphasis here is in developing generalized norms of honesty and conduct supportive of rapid economic development. Though it is to be internalized by every member of the society, it should be implemented through the school system, where monitoring costs could be minimized as potential leaders in both public and private sectors go through the school system. The additional advantage of the school system, apart from serving as a medium for the internalization of norms, is that it allows innate and acquired competencies to be detected for the purpose of governance. Competence and the extent to which the generalized value of honesty is internalized by those who go through the school system becomes the bases for selecting potential leaders for public and private offices. Thus, the school system is both a production system and a selection factory for future leaders. This is a step ahead of a system that simply selects honest and competent people in society (Adewole, 2015), because there might not exist an elastic supply of this kind of people. The use of the school system to train, monitor and select future leaders is advocated. A simple model of how this kind of process will engineer economic development by deterring corruption is presented in section five. If we could use the school system to achieve this, then other means of socialization would be spontaneously re-engineered to achieve the same objective of good governance. Organizations outside of the school system and spread across small communities in any specific society will form appropriate networks of relationships for internalized norms to have increasing returns to economic development. This approach promotes positive institutional change, because its leads to the accretion of new values, sufficiently powerful to be self-enforcing.

There are sufficient reasons for us to believe that this approach will be useful complements to large-scale institutions which are not self-enforcing in many developing countries and generally unable to prevent excessive opportunism in public and private affairs. It will offer ample support to community level governance without any interference. It helps where information asymmetry and social distance impede the monitoring of agents. It can be equally be helpful when information about cheating cannot sustain cooperation and there is effective enforcement mechanism in place (Dixit, 2001). It is therefore possible to have self-enforcing honesty as the size of governance extends beyond the optimal size.

They offer a unique social focal point and solve coordination problems among players who are unsure of how others will behave, particularly in non-repeated impersonal transactions. The social focal point can remain for a long time, because they will be passed from one generation to the next one (Bisin, Topa and Verdier, 2004). Doepke and Zilibotti (2008) model show how parent preference formation under financial market imperfections shapes their children's preference in response to economic incentives. It is this preference formation that explains the socio-economic transformation that followed the industrial revolution, allowing children of the urban middleclass to upstage the landed aristocrats. Thus, wealth constraint as a barrier against entrepreneurship cannot explain why wealthier aristocrats could not take advantage of industrialization in Great Britain (Doepke and Zilibotti, 2005). 
In Tabellini (2008) model, parents choose what values to transmit to their children, and this choice is dependent on spatial patterns of external environment and the potential kinds of transactions in the future. Drawing on the sociological concept of the norms of good conduct, Tabellini argues that generalized morality, which extends beyond the local level, will not operate if the external enforcement of cooperation is localized. But the political selection advocated in Adewole (2015) expands the scope of legal enforcement beyond the local level so that incentives now exist for parents to inculcate appropriate values. If honest and competent people are selected into public and private offices, we can broaden the scope of enforcement in the external environment beyond local communities so that cooperation can be fostered. Instilling appropriate norms can mitigate the effects of parental economic support and parental altruism on children work effort (Linbeck and Nyberg, 2006). We therefore avoid a situation where elites holding political power and working in the bureaucracy have amoral disposition to public service and a moral disposition to their small communities (Ekeh, 1975). This will create social structures that will support market transactions of considerable magnitude, though there is an external and impartial agent to enforce compliance. There is social capital embedded in the social formation which guides relations with friends and strangers and that continuously gives support to this environment for impersonal free market exchange. It cannot arise spontaneously (Platteau, 1996) but has to be nurtured through the school system and other media of socialization.

\subsection{Long Run Leadership Selection Model}

One obvious assumption of the selection model previously outlined is that there already exists a pool of honest and competent individuals in the society, from which we can draw leaders required to fulfill national aspirations. More than anything else, the literature on behavioural economics has been replete with evidences proving a considerably large fraction of humans are essentially unselfish in their relationship with others. (see Fehr and Schmidt (2001) for a review of the literature). Since the benefits of good governance extends beyond the person who provides it, it is important that the larger society be more involved in the process that leads to the production of the individuals that can be depended upon to provide quality leadership. Given that positive externalities are often associated with high quality political leadership, it is the responsibility of the larger society to make sufficient investment in the training of men in both ethical and human capital skills who will provide her with high quality political leadership. In a letter to John Adams, Jefferson (1813) puts it in this brilliant way

And had another which I prepared been adopted by the legislature, our work would have been complete. It was a bill for more general diffusion of learning. This propose to divide every counties into wards of 5 or 6 miles square, like your townships; to establish in each ward a free school for reading, writing and common arithmetic; to provide for the annual selection of the best subjects from the schools who might receive at the public expense the higher degree of education at a district school; and from this district schools to select number of the most promising subjects to be completed at a university, where all the useful sciences should be taught. Worth and genius would thus have been sought out from every condition of life, and completely prepared by education for defeating the competition of wealth and birth for public trusts. My proposition had for a further object to impart to these wards those portions of self government for which they are best qualified, by confiding to them the care of their poor, their roads, police, elections, the nomination of jurors, administration of justice in small cases, elementary exercises of militia, in short, to have made them little republics, with a Warden at the head of each, for all those concerns which, being under their eye, they would better manage than the larger republics of the country or state. (pp. 3-4)

Jefferson's proposition relies on the use of the different hierarchies of education to sort out the best set of people, those he called the natural aristocrats from the rest of the society and allow them to govern the larger society. The model we propose in this section is along the line of the suggestion offered by Jefferson which would ensure the continuous production of honest and competent leaders, both for the private and public sectors. Though the home could in fact play a significant role in achieving this specific objective, it is presently incapable of doing this because the continuous expansion of market has subsequently led to the reduction in the time parents allocate to domestic activities. Given the fact that children are time-intensive goods, rising cost of time for both parents in the family implies that they are hardly around to impart their children with the right set of values; particularly those that encourage skill and ethical capital acquisition. The school system therefore becomes a signaling mechanism for potentially great leaders.

On the more positive side, schools could be used to teach values to promote and sustain optimum social welfare. Some societies have created elite schools and military academies for this special purpose (Akerlof 1983). Akerlof's paper presents three models: the first one showing the institutional structure that will encourage parents to teach their children to be honest. The second shows how class loyalty is generated with the wealthy showing concerns for the poor. The third model shows how loyalty to institutions, such as the state, is in fact advantageous. With these branded schools, information asymmetry about leadership quality, in terms of competence and honesty, is essentially reduced. The public, which is interested in good government, rely on these elite schools for political leaders. The public regards graduates of these schools as being patriotic and capable of sacrificing self-interest for 
the common good. According to Akerlof (1983),

In Britain, Oxford and Cambridge and, for some graduates, the public schools prior to University- teach loyalty to British values in general, and government in particular. In addition, there appear to be considerable loyalty to fellow graduates. As one indication of this loyalty, most MPs of both the Labour and Conservative parties are graduates of these two Universities; more remarkable still, eighteen of twenty-two of Mrs. Thatcher's current cabinet members are graduates of public schools, only two are nongraduates of Oxbridge or the ArmyNavy services academies. (p. 61)

When appropriate values are taught, the moral $\operatorname{cost}^{1}$ can at least remain constant as the membership of a given institution grows over time. This is far more important for public institutions in societies where government size in relation to the overall economy has grown considerably overtime. Also important for our model is the Mckenzie's (1977) which regards ethical values and rules as products of an elaborate production process which starts at birth with parental labour as a major input and continues into the formal school system. The model outlined here relies on the school system to generate reliable and accurate information on potential political leaders so that future choice would not be constrained by information asymmetry.

By using the school system, both skills and values that enhance productivity in private and public institutions are taught, and students with credible records of superior intellect, vision, skills and integrity could be tracked over time for the purpose of future political leadership. Once this system is effectively institutionalized, the incentive system now exist for parents to devote the limited time they have to teaching productive skills and values beneficial to society.

Long Run Equilibrium School Model. To start this analysis, let us relate these leadership virtues of competence and honesty to the well established concept of multiplier in conventional macroeconomics. These positive virtues ensure that the resulting multiplier, which we call the leadership multiplier, is a lot bigger than traditional government or investment multiplier. The larger the leadership multiplier, the greater the level of social output. Thus, the bigger the size of a country's vision for her future, like the publicly declared desire of the government to make Nigeria one of the 20 biggest economies in the world, the larger must be her leadership multiplier and the more compelling is the need to formalize school institutions for leadership training.

In a four-sector open economy model with lump-sum tax, the traditional government expenditure multiplier $\left(\mathrm{K}_{\mathrm{G}}\right)$ is presented in this form:

$K_{G}=\frac{\Delta Y}{\Delta G}=\frac{1}{1-b+d}$

Where $\Delta \mathrm{Y}$ and $\Delta \mathrm{G}$ represent changes in national output and change in government expenditure respectively, while ' $b$ ' and ' $d$ ' stand for marginal propensity to consume and marginal propensity to import respectively. The contention here is that for a society to secure a given change in the level of output $(\Delta Y)$, it must devote part of it resources to training people who are ethically sound and professionally competent to formulate policies and handle many other issues bordering on people's welfare. Therefore, the quantum of change in output $(\Delta \mathrm{Y})$ which is our approximate measure of social welfare is directly dependent on $\mathrm{K}_{\mathrm{G}}$ in conventional macroeconomics text. In our context here, $\mathrm{K}_{\mathrm{G}}$ is positively related to the degree of honesty (h) of the political leaders who are custodians of state funds and competence (c) level of these leaders. We can then rewrite equation (1) as

$$
K_{G}=\frac{\Delta Y}{\Delta G}=\frac{c . h .}{(1-b+d) T_{s}}
$$

where $T_{S}$ is the social costs of training the leaders. The measure of competence (c) will only take on nonnegative values. The higher it is, the greater the value of the multiplier and the higher the social output level $(\Delta \mathrm{Y})$. Honesty $(\mathrm{h})$ measures the fraction of state resources converted to private use and transferred out of the system as is most often the case with looted funds. The values it can take can range between 0 and 1 . It will be zero when the change in government expenditure $(\Delta \mathrm{G})$ is wholly converted to private use and one (1) when it is completely used for public welfare. Though $\mathrm{T}_{\mathrm{S}}$ could be a huge nonnegative magnitude, a properly structured selection process will yield a considerable social payoff when only honest and competent leaders are chosen. In Nigeria, we have three tiers of government each with it own fiscal responsibility. We can therefore decompose equation (2) to reflect these levels of government and relate it to change in output $(\Delta \mathrm{Y})$.

$\Delta Y=\frac{\Delta G c_{f} \cdot h_{f}}{(1-b+d) T_{S}^{f}}+\frac{\sum \Delta G c_{s} \cdot h_{s}}{(1-b+d) T_{S}^{s}}+\frac{\sum \Delta G c_{L} \cdot h_{L}}{(1-b+d) T_{S}^{L}}$

All symbols in equation 3 have the same connotations as before except that the subscripts ' $\mathrm{f}$ ', ' $\mathrm{s}$ ' and ' $\mathrm{L}$ ' denotes federal government, state government and local government respectively. The decomposition in equation 3 is important because it allows the sorting of individuals into various levels of government using the quality of

\footnotetext{
${ }^{1}$ Defined by Buchanan (1965) as the failure of an institution to produce optimal public good as its members fail to stick to a set of ethics.
} 
schools attended as an approximate indicator of competency and the first and second screening processes as true indicators of honesty and competence.

In addition to the specification of the first stage of the screening process, those who intend to be politicians in the long run must have undergone special curriculum training in leadership at all levels of education. This is the same as the indoctrination we discussed earlier. Mastering of the curriculum must be certified by a credible examination body, most likely an external body examining a select number of candidates presented by public and private schools across the country. Those who have gone through at least twelve years of training at primary and secondary school levels can in the long run present themselves for the first and second screening processes. Thus, the society that demands high quality leaders will also be devising the mechanism for supplying them. Going through the leadership curriculum now becomes an important precondition for getting approval to participate in politics in the long run.

Those who must now go through the second stage of the screening process must face additional constraints of proving their competence via the choice of schools they attended, the quality of which becomes the approximate indicator of competence.

Equilibrium when leaders are honest: Let us start this analysis by assuming $(1-\mathrm{h}) \mathrm{G}$ amount can be converted to private use with q probability of not been caught and penalized for stealing public good. If $\mathrm{w}$ is the wages received by political leaders and $x(1-h) G$ is the refund to be made by leaders caught, then leaders' utility from dishonesty when not caught and penalized is $\mathrm{u}(\mathrm{w}+(1-\mathrm{h}) \mathrm{G})$ and $\mathrm{u}(\mathrm{w}-\mathrm{x}(1-\mathrm{hG})$ when caught. Therefore, the expected utility $\mathrm{E}(\mathrm{u})$ from dishonesty is:

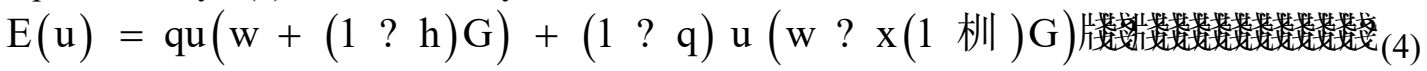

Presently, the probability of successfully stealing without being caught and penalized in one 1 (i.e. $q=1$ ). Thus, equation 4 is reduced to:

$$
\mathrm{E}(\mathrm{u})=\mathrm{u}(\mathrm{w}+(1 ? \mathrm{~h}) \mathrm{G})
$$

if he decides to be dishonest (i.e. when $\mathrm{q}=1$ ).

If he decides to be honest (i.e. when $\mathrm{h}=1$ ), the expected utility:

$$
\mathrm{E}(\mathrm{u})=\mathrm{u}(\mathrm{w})
$$

That is, he would barely collect his wages. Since $u(w)<u(w+(1-h) G)$, the rational leader steals. If $q$ is positive but less than one, the expected utility of a leader who is honest is:

$$
\mathrm{E}(\mathrm{u})=\mathrm{qu}(\mathrm{w})+(1 ? \mathrm{q}) \mathrm{u}(\mathrm{w})^{r} \text { : }
$$

However, since government expenditure $(\mathrm{G})$ is exceedingly greater than the wages $(w)$ of the leader, q.u(w) $+(1-q) u(w)<u(w+(1-h) G)$, a rational leader will decide to be dishonest. Either of the two option rewards dishonesty.

By introducing leadership curriculum at the early stages of education, we are deliberately introducing the concerns for social welfare into the utility functions of potential leaders. In other words, we are making leaders expected utility to be $\mathrm{u}(\mathrm{w}+\Delta \mathrm{Y}), \Delta \mathrm{Y}$ being the extra social output, which is an indicator of social welfare. Since $\mathrm{u}(\mathrm{w}+\Delta \mathrm{Y})$ is greater than $\mathrm{u}(\mathrm{w}+(1-\mathrm{h}) \mathrm{G}$, leaders who have undergone this leadership training at early stages of education will find it rational to be honest (Proverbs 22:6). This is also dependent on the fact that leaders that emerge from the first and second screening processes are also honest. The short run screening processes earlier outlined become additional checks on the quality of leaders that have undergone the leadership training. This is important because their activities generate salience, which sets the national code and tone of conduct. After undergoing 12 years of leadership training, the expected utility of honest leader is;

$$
\mathrm{E}(\mathrm{u})=\mathrm{u}(\mathrm{w}+\Delta \mathrm{Y})^{r}
$$

Since $\Delta \mathrm{Y}$ is the product of $\mathrm{K}_{\mathrm{G}}$ and $\Delta \mathrm{G}$,

Thus:

$$
\mathrm{E}(\mathrm{u})=\mathrm{u}\left(\mathrm{w}+K_{G} \cdot \Delta G\right. \text { 片 }
$$

When a leader is honest $(\mathrm{h}=1)$.

$$
\text { 战 }=\frac{\mathrm{c} \Delta \mathrm{G}}{(1-\mathrm{b}+\mathrm{d}) \mathrm{T}_{s}} \text { ? }
$$

Thus: 


$$
\text { 燹 }(\mathrm{u})=\mathrm{u}\left(\frac{\mathrm{w}+\mathrm{c} \Delta G}{(1-\mathrm{b}+\mathrm{d}) \mathrm{T}_{s}}\right)
$$

Since ' $c$ ' is a measure of the competence of leaders, the larger the value of $c$, the greater the expected utility of a leader and coincidentally the larger the welfare level of the society. For leaders who have gone through leadership training for at least 12 years, we would expect different levels of competence. Without any previous job history, we would find it difficult, if not impossible to distinguish leaders on the basis of their degree of competence. For federal systems with three tiers of government, we would assume three sets of honest politicians with three levels of competence, $\mathrm{C}_{\mathrm{f}}, \mathrm{C}_{\mathrm{s}}, \mathrm{C}_{\mathrm{r}}\left(\mathrm{C}_{\mathrm{f}},>\mathrm{C}_{\mathrm{s}},>\mathrm{C}_{\mathrm{r}}\right)$.

Those with competence level $\mathrm{C}_{\mathrm{f}}$ can be allowed to run for political offices at the federal level or be given political appointments. For the same reason, those with $\mathrm{C}_{\mathrm{s}}$ and $\mathrm{C}_{\mathrm{r}}$ competence levels can run or hold political appointments at state level and local government level respectively. To allocate honest politicians to various levels of government, a rule should insist that only individuals that attend universities within a range of ranking would be allowed to hold political offices ${ }^{1}$.

We motivate our model by assuming three sets of honest politicians with ' $n$ ' number in each set between 1 to $\mathrm{n}$ are in the first set $\left(\mathrm{S}_{\mathrm{T}}\right), \mathrm{n}+1$ to $2 \mathrm{n}$ are in the second set $\left(\mathrm{S}_{\mathrm{S}}\right)$ and $2 \mathrm{n}+1$ to $3 \mathrm{n}$ are in the third set $\left(\mathrm{S}_{\mathrm{L}}\right)$. Politicians in each set are to serve at three levels of government, $\mathrm{S}_{\mathrm{T}}$, at federal level, $\mathrm{S}_{\mathrm{s}}$, at state level and $\mathrm{S}_{\mathrm{L}}$ at local government level. The set representation can be presented as:
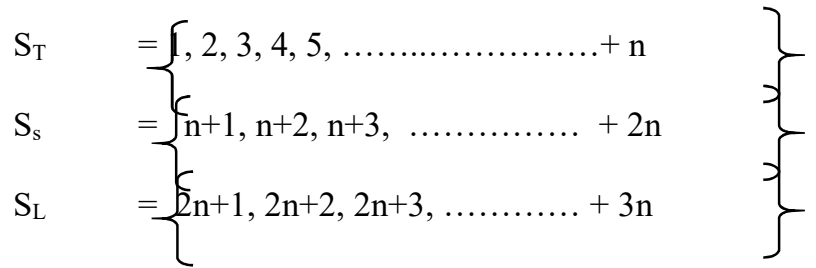

To identify politicians within a specific set, we allow them to make schooling choices using the worldwide ranking of universities. We can limit the opportunities to run for political offices or hold political appointments to honest politicians who attend $3 \mathrm{u}$ number of ranked universities.

The rankings are also limited to three, $\mathrm{U}_{\mathrm{CF}}$ is made up of the best ranked universities, $\mathrm{U}_{\mathrm{C} S}$ is the second set of universities following after $\mathrm{U}_{\mathrm{CF}}$ in quality and $\mathrm{U}_{\mathrm{C} L}$ is made up of the third ranked universities, following after $\mathrm{U}_{\mathrm{C} S}$ in terms of quality.

$$
\begin{aligned}
& U_{C F}=(1,2,3,4,5, \ldots \ldots \ldots \ldots \ldots \ldots+\mathrm{U}) \\
& U_{C S}=(\mathrm{U}+1, \mathrm{U}+2, \mathrm{U}+3,2 \ldots \ldots \ldots \ldots . .+2 \mathrm{U}) \\
& U_{C L}=(2 \mathrm{U}+1,2 \mathrm{U}+2,2 \mathrm{U}+3, \ldots \ldots \ldots \ldots+3 \mathrm{U})
\end{aligned}
$$

Politicians that pick universities in the first set $\left(\mathrm{U}_{\mathrm{CF}}\right)$ and graduate from there are allowed to contest at the federal or hold political appointments, those who choose to study at universities in the second set $\left(\mathrm{U}_{\mathrm{C} S}\right)$ are allowed to hold political offices at the state level and those who study in universities within the third set $\left(\mathrm{U}_{\mathrm{C} L}\right.$ ) are allowed to hold offices at the local government level. This signaling of school choice becomes a veritable indicator of competence. It is from this set that we can get the best set of politicians at all levels of government for the purpose of promoting economic development and enthroning true democracy rather the mere transition to civil rule. The idea of the long run does not carry any specific time connotation, but represents the period it will take a particular society to enthrone honest and competent men in offices of public trust so that the replacement of one with another will not yield a pareto-superior outcome.

The assumption that the choice of school might indicate quality is not a particularly strong one. From Akerlof (1983), the fact that prestige universities produced a large fraction of British political leaders has been established. Till date, Harvard has produced nine American Presidents and other elite American universities have produced

${ }^{1}$ Those who gain admission into these prestige universities can be given full state sponsorship. 
many others. An important study by Bishop (1989) did show that the drastic fall in the test scores, which is an indicator of school quality of American students between 1967 and 1980, had a considerable negative impact on productivity. Had the previous test score been maintained after 1967, labour quality would have been 2.9 per cent higher and GNP would have been $\$ 86$ billion more. Test score achievement of students is an approximate indicator of abilities, competences and knowledge that add to productivity in most jobs (Bishop, 1989). Besley Pande and Rao (2005) say education increases the probability of being elected for public office and reduces the chances that public resources are converted to private use.

\subsection{Summary and Conclusion}

Within the broad agenda of economic development, we suggest a model of leadership production and selection that helps to overcome the considerable inertial against take-off by supplying an optimal number of men and women required to connect the bridge between fast changing formal political and economic and slow changing informal institutions. This helps to generate economics of scale which otherwise would not be available in scattered, self-governing and well-run communities by generating common norms that could be inculcated through the school system. The selection process uses the school system to make social progress an important leadership concern and economic advancement an important part of individual utility function. In generating this special breed through the school system, the incompetent individuals are screened out from the competent individuals as well as the honest from the dishonest ones. The honest individuals are sorted into three ability categories for public governance for the three tiers of government. The ultimate aim is to motivate every family towards producing individuals whose character and competencies are compatible with the requirements of developmental states. It is to cultivate generalized morality as part of cultural capital required to prop-up pro-development leadership in the public sector and provide incentives for every member of the society to support free market transactions characterized by contractual incompleteness, asymmetric information, costly monitoring and other attributes that otherwise would encourage opportunism ex post.

\section{References}

Acemoglu, D. (2003). Why not a Political Coase Theorem? Journal of Comparative Economics, 31,620-652.

Acemoglu D and J. A. Robinson (2006). De Facto Political and Institutional Persistence, American Economic Review AEA Papers and Proceedings, Vol. 96, No. 2: 325-330.

Acemoglu and Ronbinson (2008). The Persistence and Change of Institutions in the Americas, Distinguished Guest Lecture, Southern Economic Journal, 2008, 75(2), 282-299

Acemoglu Daron, Simon Johnson and James Robinson (2001). The Colonial Origin of Comparative Advantage: An Empirical Investigation, American Economic Review 91 (5), 1369-1401.

Acemoglu Daron, Thierry Verdier and James Robinson (2004). Kleptocracy and Divide-And-Rule: A Model of Personal Rule, Journal of European Economic Association, April-May 2(2-3): 162-192.

Achebe Chinua (1987). Anthills of the Savanna, London: Heineman.

Adewole A. Musiliu (2015). Political Selection Method for Africa Democracies, Elizade University Working Paper.

Ake Claude (1996). Democracy and Development in Africa, Washington DC. The Brookings Institute.

Alonso-Terme, R., H. Davoodi, and S. Gupta. (1998). Does Corruption Affect Income Inequality and Poverty?" IMF Working Papers 98/76. Washington, DC.

Bai, Ying, and Titi Zhou (2014). Mao's Last Revolution: A Loyalty-Competence Tradeoff. Working Paper.

Besley, T., R, Pande and V. Rao (2005). Political Selection and the Quality of Government Evidence from South India," Unpublished Typescript

Besley, Timothy, and Marta Reynal-Querol (2011). Do Democracies Select More Educated Leaders? American Political Science Review 105(3): 552-566.

Besley, Timothy, Jose G. Montalvo, and Marta Reynal-Querol (2011). Do Educated Leaders Matter?" The Economic Journal 121(554): 205-227.

Bishop, John H. (1989). Is the Test Score Decline Responsible for the Productivity Growth Decline? American Economic Review, 79(1): 178 -197.

Bisin Alberto, Giorgio Topa and Thierry Verdier (2004). Cooperation as Transmitted Cultural Trait, Rationality and Society, 16(4): 477-507.

Bowles Samuel and Gintis Herbert (2002). Social Capital and Community Governance, Economic Journal, 112(483): F419-F436.

Buckley Noah, Guzel Garifullina, Ora John Reuter, and Alexandra Shubenkova (2014). Elections, Appointments, and Human Capital: The Case of Russian Mayors." Demokratizatsiya: The Journal of Post-Soviet Democratization 22(1): 87

Camerer, Colin F. and Thaler, Richard H. (1995). Ultimatums, Dictators and Manners, Journal of Economic Perspective 9, 209-19. 
Clark Gregory (2007). A Review of Avner Greif's Institutions and the Path to the Modern Economy: Lessons from Medieval Trade, Journal of Economic Literature, XLV(3): 727-743.

Collier Paul (1996). Living Down the Past: Redesigning Nigerian for Economic Growth, African Affairs, Vol. 95(380): 325-350.

Dawes, Robyn and Richard H. Thaler (1988) Cooperation. Journal of Economic Perspectives 2(3): 187-197.

Dixit Avinash (2003). Trade Expansion and Contract Enforcement, Journal of Political Economy, 111 (6): 1293 1317.

Dixit Avinash (2001). On Modes of Economic Governance, Econometrica, Vol. 71(2): 449-481.

Doepke Mathias and Fabrizio Zilibotti (2008) Occupational Choice and the Spirit of Capitalism, Quarterly Journal of Economics, Vol. 123(3): 747-793.

Doepke Mathias and Fabrizio Zilibotti (2005) Social Class and the Spirit of Capitalism, Journal of European Economic Association, 3(2-3): 516-524.

Ekeh, Peter (1975). Colonialism and the Two Publics in Africa: A Theoretical Statement. Comparative Studies in Society and History 17 (1): 91-112.

Etang Alvin, David Fielding and Stephen Knowles (2010). Does Trust Extend Beyond the Village? Experimental Trust and Social; Distance in Cameroun, CSAE Conference 2010.

Forsythe, Robert L., Joel Horowitz, N.E. Savin and Martin Sefton (1994). Fairness in Simple Bargaining Games' Games and Economic Behavior 6, 347-369.

Frank R. (1987). If Homo Economicus Could Choose His Utility Function, Would He Want One with A Conscience, American Economic Review, 77: 593-604.

Galasso, Vincenzo, and Tommaso Nannicini. (2011). Competing on Good Politicians. American Political Science Review 105(1): 79-99.

Glaeser Edward L. and Andrei Shleifer (2002). Legal Origins, Quarterly Journal of Economics, 117(4): 11931229

Glaeser Edward L. and Andrei Shleifer (2005). The Curley Effect: The Economics of Shaping the Electorate, Journal of Law, Economics and Organization, 21(1): 1-19.

Glaeser Edward, Jose Scheinkmanb, Andrei Shleifer (2003). The Injustice of Inequality, Journal of Monetary Economics 50: 199-222.

Kaufmann, D. and M. Mastruzzi. (2005). Corruption: A Trillion Dollar 'Industry? World Bank. Washington, DC.

Gray Clive and Malcolm McPherson (2001). The Leadership Factor in African Policy Reform and Growth, Economic Development and Economic Change, 40(4): 707-740.

Greif Avner (1989). Reputation and Coalitions in Medieval Trade: Evidence on the Maghribi Traders, Journal of Economic History, 49(4): 857-882.

Greif Avner (1993) Contract Enforceability and Economic Institutions in Early Trade: The Maghribi Traders' Coalition, American Economic Review, 83(1): 525-548.

Greif Avner (2006). Institutions and the Path to the Modern Economy: Lessons from Medieval Trade, Cambridge, Cambridge University Press.

Greif Avner, Milgrom Paul and Barry Weingast (1994).Coordination, Commitment, and Enforcement: The Case of the Merchant Guild, Journal of Political Economy, 102(4): 745-776.

Grossman I. Herschel and Minseong Kim (2000). Predators, Moral Decay, and Moral Revivals, European Journal of Political Economy, 16: 173-187.

Guiso Luigi, Paola Sapienza and Luigi Zingales (2008). Cultural Biases in Economic Exchange, Quarterly Journal of Economics, 124(3): 1095-1131.

Guth, Wener, Rolf Schmittberger and Bernd Schwarze (1982). An Experimental Analysis of Ultimatum Bargaining, Journal of Economic Behaviour and Organization III, 367-88.

Humphreys Macartan and Robert Bates (2005). Political Institutions and Economic Policies: Lessons from Africa, British Journal of Political Science, 35: 403-428.

Iyoha Milton (2008). Leadership Factor, Policy Making and Economic Growth in African Countries: The Case of Nigeria, Commission on Growth and Development, Working Paper No. 17.

Jones Benjamin F. and Benjamin A. Olken (2005) Do Leaders Matters? National Leadership and Growth Since World War II, Quarterly Journal of Economics, 120(3): 835-864.

Keefer, Philip and Stuti Khemani (2005). Democracy, Public Expenditures and the Poor: Understanding Political Incentives for Providing Public Services", World Bank Research Observer, 20 (1): 1-27.

Khemani, Stuti (2006) Local Government Accountability for Health Service Delivery in Nigeria, Journal of African Economies, 15: 285-312.

Khemani Stuti (2004). Political Cycles in a Developing Economy: Effect of Elections in the Indian States. Journal of Development Economics 73 (125- 154.

Laffont Jean-Jacques and David Martimort (1998). Transaction Costs, Institutional Design and the Separation of Powers, European Economic Review, 42:673-684. 
Linbeck Assar and Sten Nyberg (2006). Raising Children to Work Hard: Altruism, Work Norms and Social Insurance, Quarterly Journal of Economics, 121(4): 1473-1503.

Lizzeri, A. and N. Persico (2004). Why Did The West Extend the Suffrage? Democracy and The Scope of Government with Application to Britain's Age of Reform. Quarterly Journal of Economics, 115(May): $707-$ 765 .

Luo, Mi. (2010). Do Village Elections Select More Competent Leaders? Meritocratic Selection in China's Grassroots Democracy." Working paper

Majumdar Sumon and Sharun Mukand (2008). The Leader as Catalyst: On Leadership and the Mechanism of Institutional Change, CESIFO Working Paper 2337, Category 2 Public Choice.

Milgrom Paul, Douglass North and Barry Weingast (1990). The Role of Institutions in the Revival of Trade: The Law Merchant, Private Judges, and the Champagne Fairs, Economics and Politics, 2(1)-1-23.

North D.C and B. Weingast (1989). Constitutions and Commitment: The Evolution of Institutions Governing Public Choice in Seventeenth-Century England, Journal of Economic History, 49, No. 4: 803-832.

Nunn Nathan (2008) The Long Term Effects of African Slave Trades, Quarterly Journal of Economics, 123 (1): 139176 .

Nunn Nathan and Leonard Wantchekon (2011). The Slave Trade and the Origins of Mistrusts in Africa, American Economic Review, 101(7): 3221-3252.

Ostrom Elinor and Gordon Whitaker (1973). Does Local Community Control of Police Make a Difference? Some Preliminary Findings, American Journal of Political Science, 17(1): 48-76

Ostrom Elinor, James Walker and Roy Gardner (1992). Covenant With and Without A Sword: Self-Governance is Possible, American Political Science Review, 86(2):404-417.

Ostrom, Elinor (1990). Governing the Commons: The Evolution of Institutions for Collective Action. New York: Cambridge University Press.

Ostrom, Elinor (1992). Crafting Institutions for Self-Governing Irrigation Systems. San Francisco: Institute for Contemporary Studies.

Ostrom, E., Schroeder, L. \& Wynne, S. (1993). Institutional Incentives and Sustainable Development: Infrastructure Policies in Perspective. Boulder, CO: Westview Press.

Ostrom, E., Walker, J. \& Gardner, R. (1994). Rules, Games, and Common-Pool Resources. Ann Arbor: University of Michigan Press.

Platteau Jean-Phillipe (1996). Behind the Market Stage Where Real Societies Exist-Part II: The Role of Moral Norms, Journal of Development Studies, 30(3): 753-817

Pretty Jules and Hugh Ward (2001). Social Capital and the Environment, World Development 29(2): 209-227, 2001

Przeworski, A., Alvarez, M.E., Cheibub, J.A. and Limongi, F. (2000) Democracy and Development: Political Institutions and Well-being in The World 1950-1990 (Cambridge: Cambridge University Press).

Reinikka, Ritva and Jakob Svensson (2004). Local Capture: Evidence from a Central Government Transfer Program in Uganda, Quarterly Journal of Economics, 119 (2): 1-28.

Robinson James and Ragnar Torvik (2005). White Elephants, Journal of Public Economics, 89: 197-210.

Shleifer Andrei and Robert W. Vishny, (1994). Politicians and Firms, Quarterly Journal of Economics, 109(4): 995-1023.

Roth, Alvin E., Vesna Prasnikar, Masahiro Okuno-Fujiwara and Shmuel Zamir (1991). Bargaining and Market Behaviour in Jerusalem, Ljubljana, Pittsburgh, and Tokyo: An Experimental Study, American Economic Review 81: 1068-95.

Sethi Rajiv and E. Somanathan (1996). The Evolution of Social Norms in Common Property Resource Use, American Economic Review, 86(4): 766-788

Stasavage David (2002a). Credible Commitment in Early Modern Europe: North and Weingast Revisited, Journal of Law, Economics and Organization, 18(1): 155-185.

Stasavage David (2002a). Private Investment and Political Institutions, Economics and Politics, Vol. 14(1): 41-63.

Stasavage David (2003). Public Debt and the Birth of the Democratic State: France and Great Britain, 1688-1789, Cambridge University Press, Political Economy of Institutions and Decisions Series.

Stasavage David (2007a). Cities, Constitutions, and Sovereign Borrowing in Europe, 1274-1785, International Organization, 61: 489-525.

Stasavage David (2007b). Partisan Politics and Public Debt: The Importance of the 'Whig Supremacy' for Britain Financial Revolution, European Review of Economic History, 11: 123-153.

Suleiman, Ramzi (1996). Expectations and Fairness in a Modified Ultimatum Game', Journal of Economic Psychology 17, 531-554.

Sussman Nathan and Vishay Yafeh (2005). Constitutions and Commitment: Evidence on the Relations Between Institutions and the Cost of Capital, Unpublished Mimeo, Hebrew University of Jerusalem 
Tabellini Guido (2008). The Scope of Cooperation: Values and Incentives, Quarterly Journal of Economics, 123(3): 905-950.

Tirole Jean (1996). A Theory of Collective Reputations (with applications to the persistence of corruption and to Firm Quality), Review of Economic Studies, Vol. 63(1): 1-22.

Weingast, Barry (1997). The Political Foundations of Democracy and the Rule of Law, American Political Science Review, Vol. 91(2): 245-263.

Waroboko Nimi (1998). A Theory of the Canoe House Corporation, African Economic History, 28: 141-172. 